\title{
CORRELATION CHART OF FRONTIER FORMATION FROM GREENHORN RANGE, SOUTHWESTERN MONTANA, TO MOUNT EVERTS IN YELLOWSTONE NATIONAL PARK, WYOMING
}

\author{
B y \\ R.G. Tysdal, T.S. Dyman, D.J. Nichols, and W.A. Cobban
}

\section{INTRODUCTION}

The Upper Cretaceous Frontier Formation in southwestern Montana was deposited in the foreland basin of the Cordillera in the west and shelf facies of the foreland in the east. Lateral and vertical changes in the lithology of the formation reflect both depositional environments and regional tectonism. The measured sections presented here form a $120-\mathrm{km}$ (75-mi) transect that is about normal to the axial trend of the mid-Cretaceous seaway in which the marine rocks of the formation were deposited, and about normal to the orogenic trend in the hinterland to the west (fig. 1). During the Late Cretaceous to early Tertiary Laramide orogeny, Cretaceous strata in southwestern Montana were deformed and foreshortened (telescoped) by eastward transport of strata above major thrust faults. Frontier rocks of the Madison Range composite section and the Mount Everts section are not known to be separated by any major Laramide-age thrust faults that would have moved the sections closer together than they were when deposited, and hence, the facies present are broadly similar. Frontier strata of the Ruby River section, in the Greenhorn Range, however, lie within a thrust plate that is bordered on the east by the Hilgard thrust fault (fig. 1). The plate moved eastward during the Laramide orogeny and the facies of the Frontier present within it differ significantly from those exposed farther east, both in depositional environments and thicknesses.

The purpose of this report is to review stratigraphic relationships and nomenclature for the Frontier Formation in the region of the measured sections, and to discuss contact relationships with overlying and underlying formations. These goals are accomplished through the presentation of new data, including the faunal and palynofloral identifications and the four measured sections displayed graphically in this report, and the reinterpretation of existing data. Regional stratigraphic relationships are shown in figure 2, and thickness relationships for the measured sections are illustrated in figure 3. In discussing stratigraphic relationships, we proceed from east to west, from shelf to foreland basin. All megafossils reported here, including those in cited references, w're identified by co-author W.A. Cobban and are shown in tables 1 and 2. All palynomorphs, including those in cited references, were identified by co-author D.J. Nichols and are shown in tables 3 and 4 . In the citation of previous studies, we have attempted to include all relevant M.S. and Ph. D. theses, but others, of which we are unaware, may exist.

\section{MEASURED SECTIONS}

General locations of the measured sections are shown in figure 1, and detailed locations are giver on the chart. The four sections were measured originally by Tysdal; the Ruby River section was partly remeasured with the help of Dyman. None of the sections have been published previously. The Frontier Formation in the Madison Range is shown in a composite of two measured sections, about 21 km (13 mi) apart: the section at Lincoln Mountain represents the lower part of the formation, the section at Big Sky represents the upper part (fig. 1). The four sections were measured where exposures are the best that we know of in their general areas. All sections were measured with a Jacob's staff equipาed with a hand level.

The measured sections are shown here in a computer-generated graphic format produced by the SRG (Stratigraphic Report Graphic), a stratigraf hic applications program developed by the U.S. Geological Survey and Petroleum Information Corporation of Denver, Colo. The SRG accepts sedimentologic, paleontologic, lithologic, paleoecologic, and nomenclatural data for outcrop sections and cores, and displays these data in a scalevariant format (Petroleum Information Corporation, 1984; Dyman and others, 1985). The SRG is 
proprietary to Petroleum Information Corporation, but is available by contract to the U.S. Geological Survey for a variety of research applications.

\section{PREVIOUS WORK}

Early workers in the areas of the four measured sections commonly conducted reconnaissance studies and used map units that encompassed thick sequences of strata. These thick stratigraphic units were subdivided by later workers into several formations, including the Frontier Formation. Only the early studies that used the thick sequences of strata are mentioned in this section. Studies that concerned the Frontier directly are cited later for each measured section where appropriate in the discussions of contacts, paleontology, and correlation. In Yellowstone National Park, early studies began in the late 1800 's, whereas in the Greenhorn Range the earliest studies did not begin until about the middle of the 1900 's.

In the northern part of Yellowstone National Park, strata of the Frontier Formation were included in the Colorado Formation by Iddings and Weed $(1894,1899)$ and Hague (1896). Directly north of the park, at Cinnabar Mountain (locality $C M$, fig. 1 [the same locality was denoted by $D S$, for Devil's Slide, in Tysdal and others, 1989b]), rocks of the Frontier were mapped within the Colorado Group by Iddings and Weed (1894) and Calvert (1912).

In the Madison Range, early studies, as well as some published in recent years, generally involved mapping in which the workers did not distinguish Frontier strata from the overlying and underlying marine Cretaceous rocks. Frontier strata are part of a unit mapped as "Colorado and Montana formations" (Peale, 1896), Colorado Group (Becraft and others, 1970; Garihan and others, 1983), and an unnamed unit (Swanson, 1950). Along the western flank of the central part of the Madison Range, Hadley (1969a, 1980) used the name Frontier Formation for a thick succession of strata that included the Frontier Formation as used here, but also included several formations that underlie and overlie the Frontier as now defined.

In the Greenhorn Range and the contiguous northern part of the Gravelly and Snowcrest Ranges, reconnaissance work was conducted by Klepper (1950), who assigned strata of the Frontier to the Colorado Group. Mann $(1954,1960)$ assigned the same strata to the Colorado Formation. McBride (1988) mapped Frontier strata in the central part of the Snowcrest Range as part of his map unit of Blackleaf and Frontier Formations undivided, whereas Sheedlo (1984) did not apply a name to equivalent strata in the northern part of the range.

\section{STRATIGRAPHY}

Frontier strata of the Madison Range composite section and the Mount Everts section in the eastern part of the region considered here record deposition in a relatively stable, slowly subsiding shelf setting--a continuation of conditions that existed during deposition of Lower Cretaceous rocks. In contrast, Upper Cretaceous rocks of the much thicker Ruby River section in the Greenhorn Range record deposition in a rapidly subsiding foredeep of the foreland basin, reflecting a change in stability from that which existed during deposition of the Lower Cretaceous rocks. The nomenclature, however, does not change, although a wide variety of lithologies and thicknesses commonly are assigned to the Frontier Formation in Wyoming and southwestern Montana.

Lower and Upper Cretaceous formations that underlie the Frontier in the area of the measured sections also record deposition in a fairly stable shelf setting; lithologies of individual formations are fairly uniform, and the nomenclature also is uniform. In ascending order, the Lower and Upper Cretaceous formations are the Thermopolis Shale and Muddy Sandstone (Lower Cretaceous), and Mowry Shale (Upper Cretaceous) (fig. 2). West and southwest of the Greenhorn Range, the lithology of these formations gradually changes, and the nomenclature reflects this change. An arbitrarily chosen geographic line of demarcation (not shown in fig. 1) for the change in nomenclature lies just south of the Ruby River section, in the middle of the valley separating the Greenhorn and Gravelly Ranges from the Snowcrest Range (Tysdal and others, 1989a, b). Lithic correlatives of the Thermopolis, Muddy, and Mowry lie within the Blackleaf Formation in the Snowcrest Range and areas farther west.

Strata directly above the Frontier in the Mount Everts and Madison Range areas are assigned to the Cody Shale. No Cody strata are known to occur in the Greenhorn Range or the nearby Gravelly and Snowcrest Ranges (fig. 2).

\section{MOUNT EVERTS SECTION}

Frontier strata of the Mount Everts section (fig. 1, locality $M E$ ) in the northern part of Yellowstone National Park are composed chiefly of medium- to light-gray, fine- to medium-grained sandstone and lesser amounts of siltstone. The beds contain abundant grains of quartz, feldspar, and chert; glauconite is present locally. Light-colored bentonite and porcellanite are common interbeds in the upper part of the section. The rocks were deposited in shoreface environments and locally in upper offshore (prodelta) environments. In general, they record a 
regressive, shallowing-upward succession. Trough crossbeds and Ophiomorpha burrows oriented at a high angle to bedding attest to the shoreface setting of parts of the formation.

The Mowry-Frontier contact is conformable and gradational. Different definitions of the strata assigned to the Frontier at Mount Everts concern placement of the Mowry-Frontier contact. In this report, the base of the Frontier is placed at the base of the first ledge-forming sandstone above slopeforming, dark-gray muddy siltstone and silty mudstone, which we assigned to the upper part of the Mowry Shale. As thus defined, we measured a

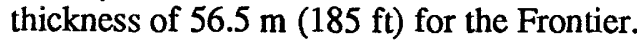

Merewether and Cobban (1986) reported about $80 \mathrm{~m}(270 \mathrm{ft}$ ) [their calculation of metric equivalence of feet] of Frontier strata at Mount Everts. Rocks that we placed in the Mowry Shale contain a sandstone unit about 11.5-15 $\mathrm{m}(38-49 \mathrm{ft})$ beneath the base of the Mowry-Frontier contact as we chose it; if the sandstone were considered the base of the Frontier, the Frontier thickness would be $71.5 \mathrm{~m}(234 \mathrm{ft})$, closer to the thickness measured by Merewether and Cobban (1986). We did not include this sandstone in the Frontier because it crops out only locally and does not provide a mappable base for the formation.

Fraser and others (1969) measured $151 \mathrm{~m} \mathrm{(497}$ $\mathrm{ft}$ ) of Frontier at Cinnabar Mountain (fig. 1, locality $C M$ ) directly north of Yellowstone National Park. They described the formation as consisting of upper and lower sandstone members, each about $17 \mathrm{~m}$ (55 $\mathrm{ft}$ ) thick, separated by a medial shale member. A tripartite nature also characterizes the Frontier where measured near McLeod $80 \mathrm{~km}(50 \mathrm{mi})$ northeast of Gardiner (fig. 1, locality $M L$ ); here, the lower sandstone member is more than $30 \mathrm{~m}(100 \mathrm{ft})$ thick and forms a cliff (Tysdal, unpub. data). The lower sandstone near McLeod thins toward Cinnabar Mountain, where it contains much interbedded siltstone and mudstone.

Strata of the medial shale unit of the Frontier at Cinnabar Mountain are similar to those in the upper part of the Mowry Shale at Mount Everts and are included as part of the Mowry in some areas. Where the lower sandstone of the Frontier is poorly exposed, where it contains a large amount of intertongued siltstone and mudstone, or where it is absent, the two units must be treated as one and mapped as the Mowry Shale. Fossils are needed to distinguish the Mowry from the fine-grained clastic rocks of the Frontier equivalents.

Differences in reported thickness of the Frontier are related to placement of the MowryFrontier contact. Different interpretations of the thickness of the Frontier at Mount Everts and at Cinnabar Mountain can be placed in perspective by comparing the composite thickness of the Frontier and the underlying Mowry Shale. For the combined
Mowry and Frontier at Cinnabar Mountain, F-aser and others (1969) measured a total thickness of 2.50 .2 $m(821 \mathrm{ft})$. Wilson (1934) also measured the Cretaceous rocks at Cinnabar Mountain, assignirg 91 $\mathrm{m}(300 \mathrm{ft})$ to the Frontier and $64 \mathrm{~m}(210 \mathrm{ft})$ to the Mowry; his Thermopolis Shale unit (beneatr the Mowry) contains an additional $94 \mathrm{~m}$ (310 ft) of s?ndy shale above a sandstone unit that most likely is the Muddy Sandstone. The combined thickness of the Frontier, Mowry, and sandy shale that we believe is part of the Mowry is $250 \mathrm{~m}(820 \mathrm{ft})$.

Ruppel $(1972$, p. 28) reported a thickness of

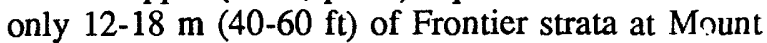
Everts, but he presented no measured section with which we could compare our data. Ruppel (1972, p. 28) stated that the sandstone mapped in the northern part of Yellowstone National Park is correlative with the lower sandstone member of the Frontier ir the Gardiner area as mapped by Fraser and others (1069). We disagree with this interpretation, and with Ruppel's statemeni (p. 29) that the middle shale and upper sandstone of Fraser and others (1969) are really part of the Cody Shale. We measured the Cinnabar Mountain section and conclude that the Frontier-Cody contact was placed accurately by Fraser and others (1969). The difference in thickness reported fo- the Frontier at Cinnabar Mountain, as with that reported at Mount Everts, is in placement of the MowryFrontier contact.

At Mount Everts, we measured $201 \mathrm{~m}(66 ? \mathrm{ft})$ of Mowry and Frontier combined. Brown (1957) measured $152 \mathrm{~m}$ (498 ft) of Mowry and Frontier combined at Mount Everts, but it is clear from his text, his illustrated line of section measured, and from the absence of bentonitic strata known to be present in the lowermost part of the Mowry in the area of his section, that his thickness for the Mowry did not include the lowermost part of the Mowry.

The Frontier-Cody contact is paraconformable at Mount Everts. Basal strata of the Cody Shale are middle Coniacian in age, whereas those of the uppermost Frontier are middle Turonian in age (Merewether and Cobban, 1986) (see paleonto'ogy discussed in following paragraphs). Pebbles are present locally at the top of the Frontier in the vicinity of Mount Everts, forming a zone 1-2. in. thick (exaggerated in the measured section). The pebbles may represent a transgressive lag gravel related to deposition of the overlying Cody Shale, or they may be genetically related to Frontier strata: we interpret the gravel as part of the Frontier.

The age of the Frontier at Mount Everts is Cenomanian and Turonian. The uppermost sandstone unit of the Frontier of the Mount Everts section yielded fauna of the middle Turonian Collignoniceras woollgari zone (table 1, Mesozoic locality D11S21). Marine palynomorphs of early to middle Cenomanian age were collected by us from a carbonaceous shale 
lens within sandstone in the lower part of the Frontier at Mount Everts (table 3, paleobotany locality D6799-A). A significant time break must therefore lie within the sequence between the sample horizon of the shale lens (unit 14 of $M E$ section) and that of the $C$. woollgari horizon (unit 36 of $M E$ section). Palynomorphs from unit 30 (paleobotany locality D6799-B) of the measured section, between the previous palynomorph horizon and the horizon of $C$. woollgari, have a broad age-range of CenomanianTuronian, and thus do not provide an age constraint. Merewether and Cobban (1986) considered the entire sequence of marine sandstones to be middle Turonian in age, and that a middle Cenomanian-early Turonian hiatus existed between the sandstone and underlying "nonmarine" strata at the base of the Frontier.

The early to middle Cenomanian age of our palynomorphs in the basal part of the Frontier at Mount Everts indicates that both (1) the medial shale member of the Frontier at Cinnabar Mountain and its Mount Everts lithic equivalent (which we placed in the Mowry) and (2) the lower sandstone member of the Frontier at Cinnabar Mountain and its equivalentage strata at Mount Everts (which we also placed in the Mowry) may be as old as early Cenomanian. More detailed biostratigraphic work needs to be done before a more detailed assessment can be made concerning the age of these strata.

\section{MADISON RANGE COMPOSITE SECTION}

The Frontier Formation in the Madison Range was first distinguished from other Cretaceous strata by Tysdal and Simons (1985) during mapping in the central and southern part of the range. The formation generally is not well exposed and at no place in the mapped area was a continuous section found for the entire formation. Two measured sections are presented here and, on the basis of their megafaunal content, are interpreted as comprising a composite section of the Frontier. The lower part of the formation is best exposed at Lincoln Mountain (fig. 1) and the upper part is nearly completely exposed in a roadcut west of the village of Big Sky, about $21 \mathrm{~km}$ $(13 \mathrm{mi})$ to the north.

Megafossils from the top of the Lincoln Mountain section are of the early middle Turonian Collignoniceras woollgari faunal zone. Megafossils obtained from near the middle of the Big Sky section are fragmented and not abundant, but are interpreted to represent the late middle Turonian Prionocyclus hyatti faunal zone. Co-author W.A. Cobban believes that the weight of the evidence favors interpretation of the faunal remains from Big Sky as probable specimens of Scaphites arcadiensis Moreman and Inoceramus flaccidus White, both species of the $P$. hyatti zone. Cobban further believes a possibility exists that the faunal remains could be of species from the older $C$. woollgari zone, although this is not the favored interpretation. If the latter possibility is true, th en the two measured sections could contain some timeequivalent strata. However, the two sections do not share a key bed or like sequences, and fossils of the $P$. hyatti zone were obtained from uppermost strata of the Big Sky section.

The thickness of the composite section tot $1 \mathrm{~s}$ $217 \mathrm{~m} \mathrm{(713} \mathrm{ft).} \mathrm{At} \mathrm{no} \mathrm{place} \mathrm{was} \mathrm{the} \mathrm{contact} \mathrm{between}$ the upper and lower parts of the composite section exposed. We have no estimate of thickness for strata "missing" from between those present at Lincoln Mountain and those at Big Sky. The preserved thickness of the Frontier is not uniform throughout the study area. The Madison Range area was exposed to erosion following deposition of the Frontier and some strata of the upper part of the formation were removed.

\section{Lincoln Mountain section}

The lower part of the Frontier Formation is

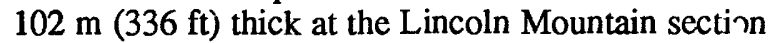
(fig. 1, locality $L M$ ) and is composed chiefly of dark-gray, fine-grained sandstone and siltstone comprised of quartz, feldspar, chert, rock fragments, and locally glauconite. Sandstone in the upper part of the section is rhythmically interbedded with mudstone and is interpreted as a delta-front sandstone. Sandstone in the lower part of the section contains abundant sedimentary structures indicative of a shallowing-upward succession of lower to middle shoreface environments. The middle part of the section seems to be mostly nonmarine and contains a thick, prominent porcellanitic tuff. An unconformity probably exists at the top of a brackish-water limestone-coquina that caps the middle part of the measured section.

The Mowry-Frontier contact is conformat ${ }^{1 e}$. and was placed at the base of the first sandstone unit above slope-forming, dark-gray mudstone and silty mudstone that was assigned to the Mowry Shale (Tysdal and others, 1989a, b). Much of the previous work in the east-central part of the Madison Ranre constitutes fairly detailed theses studies. Hall (1961), Lauer (1967), Ray (1967), Rose (1967), Bolm (1969), Kehew (1971), and Walsh (1971) used Cretaceous strata undivided, or undifferentiated, for rocks that include part or all of the Frontier Formation. Wilson (1970) and Vuke (1982, 1981) identified Frontier in their studies but assigned some of the lower Frontier strata at Lincoln Mountain to the Mowry Shale; Schwartz (1972) assigned the same strata to his Blackleaf Formation unit D, which he equated with the Mowry; and Austin and Stoever (1950) assigned the same strata to the Aspen(?) Formation, a name used in western Wyoming and 
eastern Idaho. The assignments were made, at least in part, to include porcellanitic tuff (units 13 and 14 of $L M$ section) that lies about $33 \mathrm{~m}(108 \mathrm{ft})$ above the base of the Frontier as mapped by Tysdal and Simons (1985) and Tysdal (1989) and as defined in some detail by Tysdal and others $(1989 \mathrm{a}, \mathrm{b})$. Porcellanitic tuff in the Frontier that is similar to pastel-colored porcellanitic (and bentonitic) strata in the lower part of the Mowry Shale, $84 \mathrm{~m}(274 \mathrm{ft})$ beneath the base of the Frontier at Lincoln Mountain, probably led some of the above authors to include the strata with this additional volcanic material in the Mowry. The pastel strata were assigned to the Vaughn Member of the Mowry Shale by Tysdal and others (1989b).

At Lincoln Mountain, Tysdal and others (1989a) reported palynomorphs of late Albian to early Cenomanian age from the basal strata of the Frontier (paleobotany locality D6950, table 3; unit 6 of $L M$ section). The palynomorph assemblage is now considered to be early Cenomanian in age. This reinterpretation is reflective of a new interpretation of molluscan megafossil data for the Cretaceous Western Interior (Cobban and Kennedy, 1989); age assignments of palynomorph assemblages are keyed to the molluscan fossils. The basal sandstone of the Frontier at Lincoln Mountain yielded the longranging marine brachiopod Lingula subspatulata Hall and Meek along with several other megafossils, including an unidentifiable juvenile ammonite, that are not age diagnostic (table 1, Mesozoic localities D11689, D11690). Megafossils from Mesozoic locality D11927 (table 1; unit 19 of $L M$ section), about in the middle of the measured section, are brackish-water forms that also are not age diagnostic. The early middle Turonian ammonite Collignoniceras woollgari (Mantell) (table 1, Mesozoic locality D12343) was found at the top of the Lincoln Mountain section.

\section{Big Sky section}

The upper part of the Frontier Formation is $115 \mathrm{~m}$ (377 ft) thick at the Big Sky measured section (fig. 1, locality $B S$ ). Most of the upper part of the formation consists of repeated deposits of light- to medium-gray, fine-grained sandstone and siltstone composed of quartz, feldspar, chert, and rock fragments. Hummocky crossbeds are common in some units of the sandstone and Ophiomorpha burrows occur in some of these units. These strata are interpreted as offshore mudstone and siltstone and lower to middle shoreface sandstone. The upper $25 \mathrm{~m}$ $(82 \mathrm{ft})$ consists of dark-gray mudstone and siltstone, capped by a sequence of fine-grained sandstone and siltstone-mudstone. These upper strata are interpreted as nonmarine delta-plain deposits. Thin beds (less

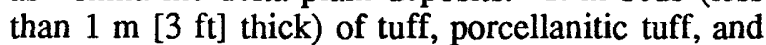
bentonite occur sparingly through the entire upper part of the Frontier in the Big Sky section. The Frontier is unconformable with the overlying Cody Shale.

Megafossils of the late middle Turonian Prioncyclus hyatti faunal zone were collected from unit 18, near the middle of the Big Sky section (table 1 , Mesozoic locality D11923), and from unit 54, the uppermost stratum (table 1, Mesozoic locality D12918). Nonmarine and brackish-water fossils that are not age diagnostic were found in delta-plain ro $k s$ beneath the $P$. hyatti fossils of the uppermost stratum (table 1, Mesozoic localities D12908, D12919, D12920, and D12921). No palynomorphs were recovered from our samples of this section.

\section{RUBY RIVER SECTION}

The entire section of the Frontier Formation measured near the Ruby River (fig. 1, locality $P R$ ) consists of interbedded medium-gray, fine- to medium-grained sandstone and interbedded olive-graen to gray mudstone and siltstone, and locally coaly mudstone and coal. These rocks are composed dominantly of quartz, chert, feldspar, and rock fragments; many of the sandstone beds have a "saltand-pepper" appearance. Strata of the lower part of the measured section represent estuarine and coaly backswamp sediments of a delta plain. Most of the upper part contains a prominent assemblage of coarse stream-channel deposits of sandstone that display erosive bases and trough crossbeds that decrease in size upward in a deposit, and that commonly are capped by plane-bedded sandstone. Associated overbank strata are represented by the olive and gray mudstone, silty mudstone, and muddy siltstone that commonly contain carbonaceous plant debris. Brackish-water and coastal sediments are present locally in the uppermost part of the section.

The Mowry-Frontier contact may be unconformable in the Greenhorn Range whare lowermost sandstone of the Frontier overlies pocrly exposed porcellanitic and bentonitic strata of the Vaughn Member of the Mowry Shale. In the Madison Range and farther east, the Vaughn is overlain by dark-gray mudstone or muddy siltstone that forms the upper part of the Mowry. No lithic equivalent of the upper part of the Mowry is present above the Vaughn Member in the area of the Frontier section in the Greenhorn Range; the strata may have been eroded, although it is possible that the up zer part never was deposited there or that equivalent (contemporaneous) strata are of different facies. The upper part of the Mowry in the Madison Range is Cenomanian in age; megafauna and palynomorphs (tables 1 and 3 ) from the base of the Frontier Formation in the Ruby River section are Cenomanian-Turonian in age, as discussed below; hence, the paleontological data are inconclusive as to 
the existence of an unconformity between the top of the Vaughn Member and the base of the Frontier in the Ruby River section.

The top of the Frontier section measured near the Ruby River is truncated by a segment of the Snowcrest thrust fault. No Cody Shale is known to occur in the Greenhorn, Gravelly, or Snowcrest Ranges. In the central part of the Snowcrest Range, about $24 \mathrm{~km}(15 \mathrm{mi})$ southwest of the Ruby River section, T.S. Dyman (unpub. data) measured about $167 \mathrm{~m}(547 \mathrm{ft})$ of uppermost Frontier strata. There, the uppermost part of the Frontier consists of interbedded olive-green mudstone and siltstone, sandstone, and shale. The Frontier is unconformably overlain by chert-pebble conglomerate and quartz arenite of the Upper Cretaceous and lower Tertiary(?) Beaverhead Group.

We measured $882.4 \mathrm{~m}(2,895 \mathrm{ft})$ of Frontier strata in the Ruby River section. Minor faults are present within the section but no strata are repeated. A covered interval occurs above the top of the section and the Snowcrest thrust fault lies within the covered interval.

Hadley $(1960,1969 b, 1980)$ assigned the strata in our Ruby River section to the Frontier Formation, but he included the underlying Mowry Shale in the Frontier as well. Schwartz $(1972,1983)$ included lowermost strata of the Frontier along the Ruby River as part of his unit $D$, which he considered part of the underlying Lower and Upper Cretaceous Blackleaf Formation. The lowermost part of the Frontier was properly assigned when measured in the study of the Blackleaf Formation and directly overlying strata in southwestern Montana by Dyman (1985a, b) and Dyman and Nichols (1988). Dyman (1985b) described about $60 \mathrm{~m}$ (197 ft) of olive-green mudstone, lithic sandstone, and shale in the lower part of the Frontier directly west of the Ruby River section. Dyman and others (1989) described as much as $2,135 \mathrm{~m}(7,000 \mathrm{ft})$ of Frontier strata south of Lima, Mont. (fig. 1), all of which is Cenomanian to Turonian in age.

Megafossils from the Ruby River section are Cenomanian-Turonian forms of brackish-water to paralic environments (table 1, localities D12922, D12923, D12354, and D12355). Basal strata of the Frontier from near the measured section presented here yielded the marine bivalve Pleuriocardia pauperculum (Meek), a Cenomanian-Turonian bivalve common in marine nearshore sandy environments (Dyman and Nichols, 1988). Klepper (1950) and Hadley (1980) each previously made two collections of megafauna from strata that are included in our measured section; these assemblages, indicative of brackish-water environments except for the marine bivalve $P$. pauperculum (Meek) reported by Klepper (1950), are listed in table 1 of this report. Hadley's (1980) collection locality D1768 probably is from the same locality as our D12355. Hadley's (1980) collection locality D1766 is higher stratigraphically than D1768 but we could not determine its stratigraphic position. Some generic names listed by Klepper (1950) and Hadley (1980) have been changed in table 1 to reflect current usage.

Assemblages of palynomorphs from the Ruby River section are generally indicative of Cenomanian through Turonian age (table 3, paleobotany localit : $s$ D6773-A, D6773-B, D6801, D6804, D6805, and D6806). The total array of fossil pollen and spoes recovered from the section is the characteristic palynomorph assemblage of nonmarine facies of the Frontier Formation in Montana and Wyoming. Species indicative of late Albian or earliest Cenomanian age are absent from the Ruby River section. Basal strata of the Frontier from near this section yielded a nonmarine assemblage of Cenomanian aspect (Dyman and Nichols, 1988). The assemblage from the middle part of the measured section (locality D6773-B) could be as young as Turonian, although most species identified are characteristic of both the Cenomanian and Turoniar.

\section{SUMMARY}

The Frontier Formation in the Greenhorn and Madison Ranges of southwestern Montana and the northern part of Yellowstone National Park in northwestern Wyoming is composed of a predominantly clastic sequence of sandstone, siltstone, and mudstone deposited in shallow-marine to marginal-marine and nonmarine environmerts. The Frontier was deposited in the foreland basin of the Cordillera in the west and a foreland shelf in the east. The four measured sections presented here form a transect transverse to the Cretaceous seaway and to the Cordillera to the west. The westernmost (Ruby River) section was thrust eastward by faults of Laramide age, whereas the eastern (Madison Rar ?e composite and Mount Everts) sections lie approximately in their original depositional positions with respect to one another.

The thickness of the Frontier Formation ranges from a minimum of $56.5 \mathrm{~m}(185 \mathrm{ft})$ at the Mount Everts section in the northern part of Yellowstcne National Park (fig. 3) to a maximum of $882.4 \mathrm{~m}$ $(2,895 \mathrm{ft})$ at the Ruby River section in the Greenhorn Range. The composite Lincoln Mountain and Rig Sky section of the Madison Range is $217 \mathrm{~m}$ (713 ft) thick. These thickness differences reflect several factors. (1) The marine shelf strata of the Mount Everts section and the Madison Range composite section were deposited in a more stable setting th an those in the more rapidly subsiding foreland basin of the Ruby River section in the Greenhorn Range in the west. (2) The Ruby River section has been thrust eastward from its original site of deposition. (3) The 
Ruby River section is incomplete, truncated by a splay of the Snowcrest thrust fault. The total thickness of the Frontier in the Greenhorn Range is unknown. (4) Thickness differences of the Mount Everts section and Madison Range composite section are due partly to post-Frontier, pre-Cody Shale erosion. Strata at the top of the Mount Everts section and at the top of the Lincoln Mountain part of the Madison Range composite section both yielded mollusks of the early middle Turonian Collignoniceras woollgari faunal zone. Younger Turonian strata are present in the Big Sky part of the Madison Range composite section and constitute about half of the preserved strata there. Fauna of the Ruby River section do not narrowly define time intervals so that age comparisons are not possible with the eastern sections.

The Frontier of the Madison Range composite section contains Cenomanian through middle Turonian strata, although only a part of each faunal stage is represented due to erosion represented by unconformities within the formation. Cenomanian and Turonian strata are present in the Mount Everts section, but again, a major time gap exists within the formation. Cenomanian and Turonian strata also characterize the Ruby River section, but the youngest age for the formation in this area is unknown because the section is truncated by a thrust fault. In addition, the hiatus represented by the post-Frontier unconformity may differ throughout the region. Agediagnostic fossils from strata higher in the Frontier than those present in the Ruby River section need to be obtained before the entire age-range of the Frontier, and the span of time represented by the post-Frontier unconformity, can be determined.

\section{REFERENCES CITED}

Austin, W.H., and Stoever, E.C., Jr., 1950, Reconnaissance geology of the south flank of Cinnamon Mountain, Gallatin County, Montana: Ann Arbor, University of Michigan M.S. thesis, $102 \mathrm{p}$.

Becraft, G.E., Kiilsgaard, T.H., and van Noy, R.M., 1970, Mineral resources of the Jack Creek Basin, Madison County, Montana: U.S. Geological Survey Bulletin 1319-B, 24 p.

Bolm, J.G., 1969, Geology of the Lone Mountain area, southwestern Montana: Moscow, University of Idaho M.S. thesis, 38 p.

Brown, W.B., 1957, Stratigraphic and structural geology of north central-northeast Yellowstone National Park, Wyoming and Montana: Princeton, N.J., Princeton University Ph. D. thesis, $176 \mathrm{p}$.

Calvert, W.R., 1912, The Electric Peak field, Park County, Montana: U.S. Geological Survey Bulletin 471-E, p. 406-422.
Cobban, W.A., and Kennedy, W.J., 1989, The ammonite Metengonoceras Hyatt, 1903, from the Mowry Shale (Cretaceous) of Montana and Wyoming: U.S. Geological Survey Bulletin 1787-L, 23 p.

Dyman, T.S., 1985a, Preliminary chart showing stratigraphic correlation and lithofacies description for the Lower Cretaceous Blackleaf Formation and lower Upper Cretaceous Frontier Formation (lower part) in Beaverhead and Madison Counties, Montana: U.S. Geological Survey Open-File Report 85-729, 9 p., 1 pl.

1985b, Measured stratigraphic sections of Lower Cretaceous Blackleaf Formation and lower Upper Cretaceous Frontier Format'on (lower part) in Beaverhead and Madison Counties, Montana: U.S. Geological Survey Open-File Report 85-431, 72 p.

Dyman, T.S., Materna, W.L., and Wilcox, L.A., 1985, Stratigraphic applications of the Geologic Analysis System (GAS) [ab .]: American Association of Petroleum Geolog: sts Bulletin, v. 69, p. 251.

Dyman, T.S., and Nichols, D.J., 1988, Stratigraphy of mid-Cretaceous Blackleaf and lower part. of Frontier Formations in parts of Beaverhead and Madison Counties, Montana: U.S. Geologinal Survey Bulletin 1773, 31 p.

Dyman T.S., Perry, W.J., Jr., Nichols, D.J., Davis, L.E., and Haley, J.C., 1989, Stratigraphy, petrology, and provenance of the Cenomanian to Turonian Frontier Formation near Lima, southwestern Montana, in French, D.E., and Grabb, R.F., eds., Geologic resources of Montana, volume 1: Montana Geologiral Society 1989 Fieldtrip Guidebook, p. 103-115.

Fraser, G.D., Waldrop, H.A., and Hyden, H.J., 19 $` 9$, Geology of the Gardiner area, Park Courty, Montana: U.S. Geological Survey Bulletin 1277,118 p.

Garihan, J.M., Schmidt, C.J., Young, S.W., and Williams, M.S., 1983, Geology and recurrent movement history of the Bismark-Spanish Peaks-Gardiner fault system, southw'st Montana, in Lowell, J.D., ed., Rocky Mountain foreland basins and uplifts: Denver, Colo., Rocky Mountain Association of Geologists, p. 295-314.

Hadley, J.B., 1960, Geology of the northern part of the Gravelly Range, Madison County, Montana, in Campau, D.E., and Anisgard, H.W., eds., West Yellowstone--earthquake area: Billings Geological Society 11th Ann ral Field Conference Guidebook, p. 149-153.

1969a, Geologic map of the Cameron quadrangle, Madison County, Montana: U.S. 
Geological Survey Geologic Quadrangle Map GQ-813, scale 1:62,500.

$1969 \mathrm{~b}$, Geologic map of the Varney quadrangle, Madison County, Montana: U.S. Geological Survey Geologic Quadrangle Map GQ-814, scale 1:62,500.

1980, Geology of the Varney and Cameron quadrangles, Madison County, Montana: U.S. Geological Survey Bulletin 1459, 108 p.

Hague, Arnold, 1896, Yellowstone National Park sheets: U.S. Geological Survey Atlas, Folio 30.

Hall, W.B., 1961, Geology of part of the upper Gallatin Valley of southwestern Montana: Laramie, University of Wyoming $\mathrm{Ph}$. D. thesis, $239 \mathrm{p}$.

Iddings, J.P., and Weed, W.H., 1894, Description of the Livingston sheet, Montana: U.S. Geological Survey Geologic Atlas, Folio 1, 4 p., maps.

1899, Descriptive geology of the Gallatin Mountains, in Hague, Arnold, and others, Geology of the Yellowstone National Park: U.S. Geological Survey Monograph 32, part 2, p. $1-59$.

Kehew, A.E., 1971, Environmental geology of part of the West Fork basin, Gallatin County, Montana: Bozeman, Montana State University M.S. thesis.

Klepper, M.R., 1950, A geologic reconnaissance of parts of Beaverhead and Madison Counties, Montana: U.S. Geological Survey Bulletin 969-C, p. 55-85.

Lauer, J.C., 1967, The stratigraphy and structure of the Snowflake Ridge area, Gallatin County, Montana: Corvallis, Oregon State University M.S. thesis, $165 \mathrm{p}$.

Mann, J.A., 1954, Geology of part of the Gravelly Range, Montana: Yellowstone-Bighorn Research Association, Contribution 190, 92 p. 1960, Geology of part of the Gravelly Range area, Montana, in Campau, D.E., and Anisgard, H.W., eds., West Yellowstone-earthquake area: Billings Geological Society 11th Annual Field Conference Guidebook, p. 114-127.

McBride, B.C., 1988, Geometry and kinematics of the central Snowcrest Range; a Rocky Mountain foreland uplift in southwestern Montana: Kalamazoo, Western Michigan University M.S. thesis, $213 \mathrm{p}$.

Merewether, E.A., and Cobban, W.A., 1986, Biostratigraphic units and tectonism in the mid-Cretaceous foreland of Wyoming, Colorado, and adjoining areas, in Peterson, J.A., ed., Paleotectonics and sedimentation: American Association of Petroleum Geologists Memoir 41, p. 443-468.
Peale, A.C., 1896, Description of the Three Forks sheet (Montana): U.S. Geological Survey Atlas, Folio 24, 10 p.

Petroleum Information Corporation, 1984, Geologic Analysis System (GAS): Denver, Colc., Petroleum Information Corporation, Technical Services Training Manual, $195 \mathrm{p}$.

Ray, J.D., 1967, Structure and stratigraphy of tl : Cinnamon Mountain area, Gallatin Count:", Montana: Corvallis, Oregon State University M.S. thesis, $148 \mathrm{p}$.

Rose, R.R., 1967, Stratigraphy and structure of pert of the southern Madison Range, Madison ard Gallatin Counties, Montana: Corvallis, Oregon State University M.S. thesis, 172 p.

Ruppel, E.T., 1972, Geology of pre-Tertiary rocks in the northern part of Yellowstone National Park, Wyoming: U.S. Geological Survey Professional Paper 729-A, 66 p.

Schwartz, R.K., 1972, Stratigraphic and petrographic analysis of the Lower Cretaceous Blackleaf Formation, southwestern Montana: Bloomington, Indiana University $\mathrm{Ph}$. $\mathrm{D}$. thesis, $268 \mathrm{p}$.

1983, Broken Early Cretaceous foreland bas in in S.W. Montana; sedimentation related to tectonism, in Powers, R.B., ed., Geolog: studies of the Cordilleran thrust belt: Denver, Colo., Rocky Mountain Association of Geologists, p. 159-183.

Sheedlo, M.K., 1984, Structural geology of th : northern Snowcrest Range, Beaverhead ard Madison Counties, Montana: Kalamazos, Western Michigan University M.S. thesis, $1: 2$ p.

Swanson, R.W., 1950, Geology of a part of th ? Virginia City and Eldridge quadrangler Montana: U.S. Geological Survey Open-File Report, Spokane, Wash., 12 p.

Tysdal, R.G., 1989, Geologic map of the Sphirx Mountain quadrangle and adjacent parts of th ? Cameron and Hebgen Dam quadrangles. Montana: U.S. Geological Survey Miscellaneous Investigations Series Map I1815 , scale 1:62,500.

Tysdal, R.G., Dyman, T.S., and Nichols, D.J., 1989a, Correlation chart of Lower Cretaceons rocks, Madison Range to Lima Peaks area, southwestern Montana: U.S. Geological Survey Miscellaneous Field Studies Map $\mathrm{M}^{-}{ }^{-}$ 2067, 16 p., 1 pl.

1989 b, Lower Cretaceous bentonitic strata in southwestern Montana assigned to Vaugl $\eta$ Member of Mowry Shale (east) and of Blackleaf Formation (west): Mountain Geologist, v. 26, p. 53-61.

Tysdal, R.G., and Simons, F.S., 1985, Geologic map of the Madison Roadless Area, Gallat'n 
and Madison Counties, Montana: U.S. Geological Survey Miscellaneous Field Studies Map MF-1605-B, scale 1:96,000.

Vuke, S.M., 1982, Depositional environments of the Cretaceous Thermopolis, Muddy, and Mowry Formations, southern Madison and Gallatin Ranges, Montana: Missoula, University of Montana M.S. thesis, $141 \mathrm{p}$.

1984, Depositional environments of the Early Cretaceous Western Interior seaway in southwestern Montana and the northern United States, in Stott, D.F., and Glass, D.J., eds., The Mesozoic of middle North America: Canadian Society of Petroleum Geologists Memoir 9, p. 127-144.
Walsh, T.H., 1971, Quaternary geology of the east portion of West Fork basin, Gallatin Courty, Montana: Bozeman, Montana State University M.S. thesis.

Wilson, C.W., 1934, Section of Paleozoic and Mesozoic rocks measured at Cinnabar Mountain, Park County, Montana, and at Mount Everts, Yellowstone National Park, Wyoming: Bulletin of the American Association of Petroleum Geologists, v. 18, p. 368-374.

Wilson, M.D., 1970, Cretaceous stratigraphy of the southern Gallatin and Madison Ranges: Moscow, University of Idaho Ph. D. thesis, 86 p.

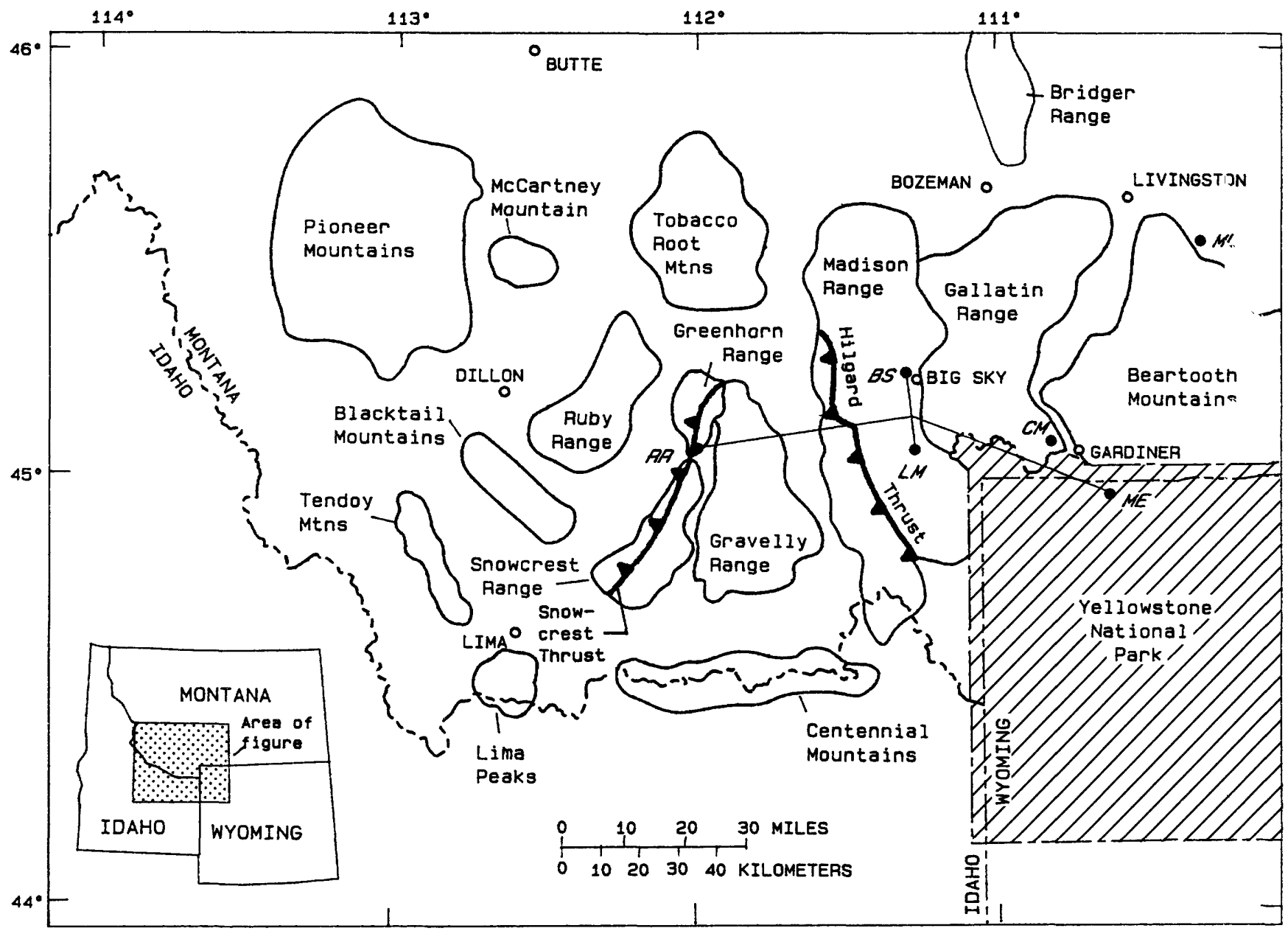

Figure 1.--Index map of geographic features and locations of measured sections of the Frontier Formation in the Greenhorn and Madison Ranges, southwestern Montana, and at Mount Everts in Yellowstone National Park, Wyoming. Abbreviations for measured sections are as follows: $B S$, Big Sky; $L M$, Lincoln Mountain; $M E$, Mount Everts; $R R$, Ruby River; $C M$, Cinnabar Mountain; $M L$, McLeod. Only the first four sections are shown on chart. 


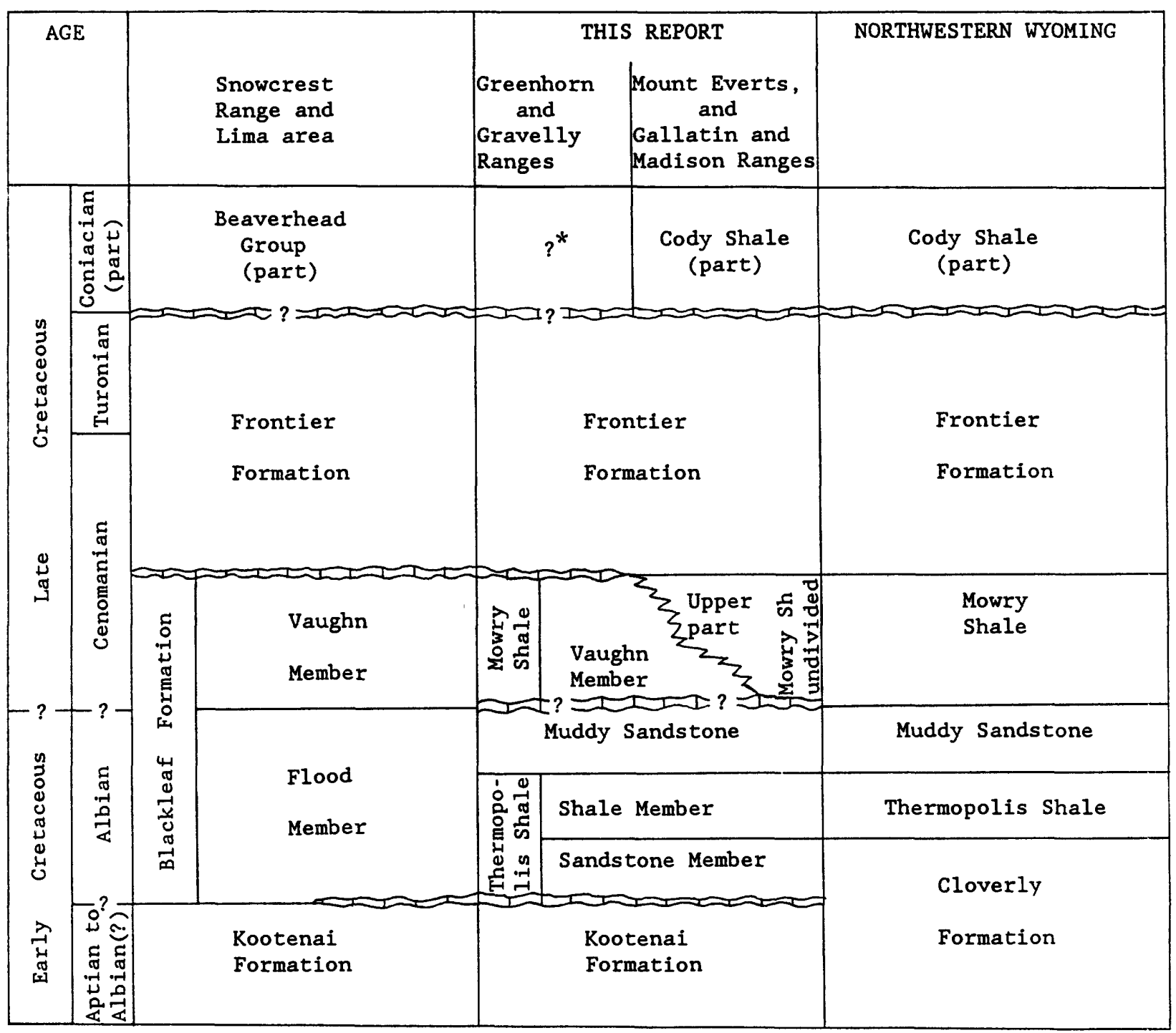

Figure 2.--Correlation chart of middle Cretaceous rocks in southwestern Montana and northwestern Wyoming. Asterisk (*) denotes section missing due to thrust fault. Placement of Lower-Upper Cretaceous boundary refle :ts new interpretation of molluscan megafaunal data for the Cretaceous Western Interior (Cobban and Kennedy, 1989). 


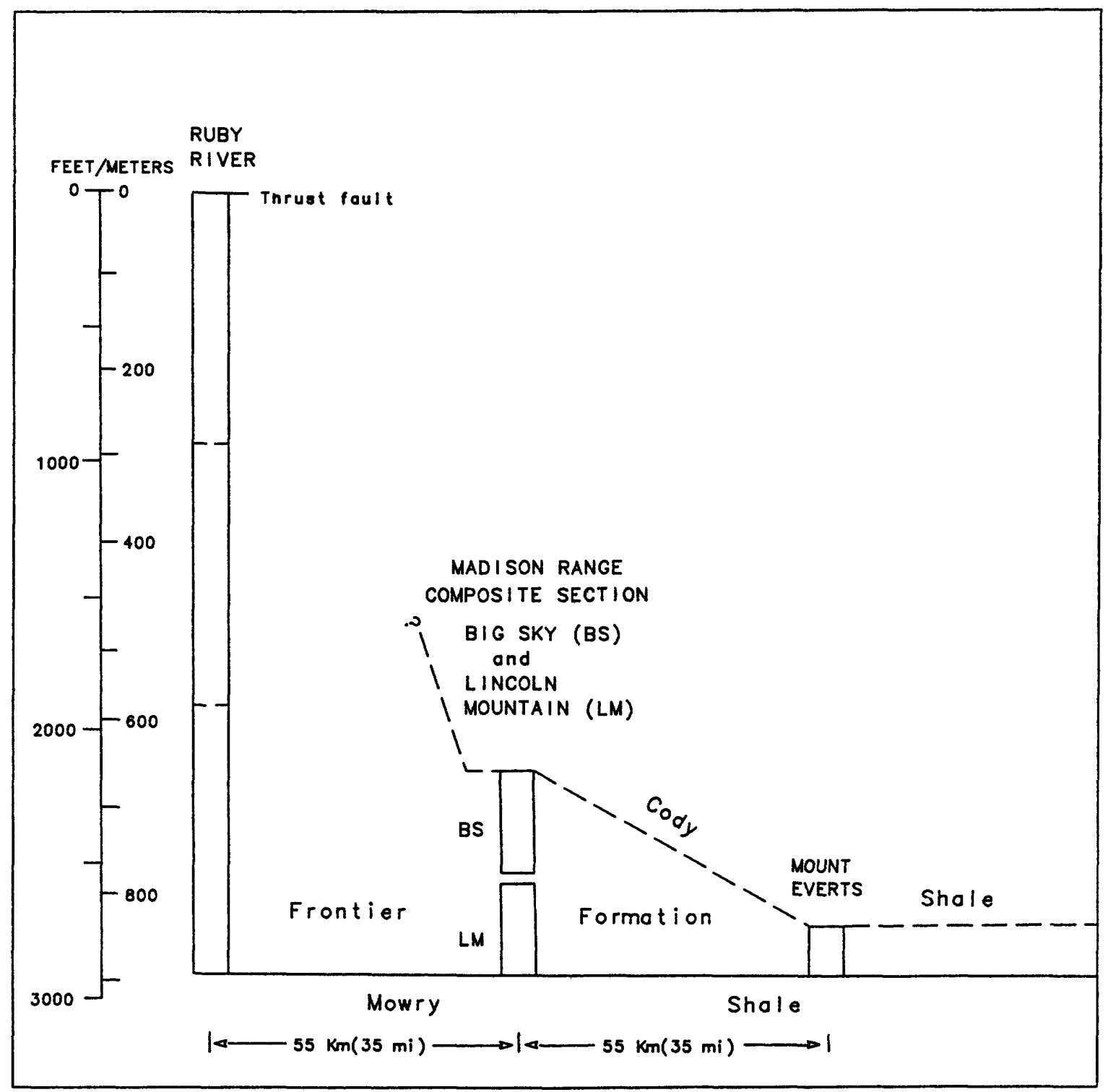

Figure 3.--Diagram of thickness relationships of the Ruby River, Big Sky and Lincoln Mountain, and Mount Everts measured sections. (Ruby River section, shown in three columns on chart, here is shown in one column.) 


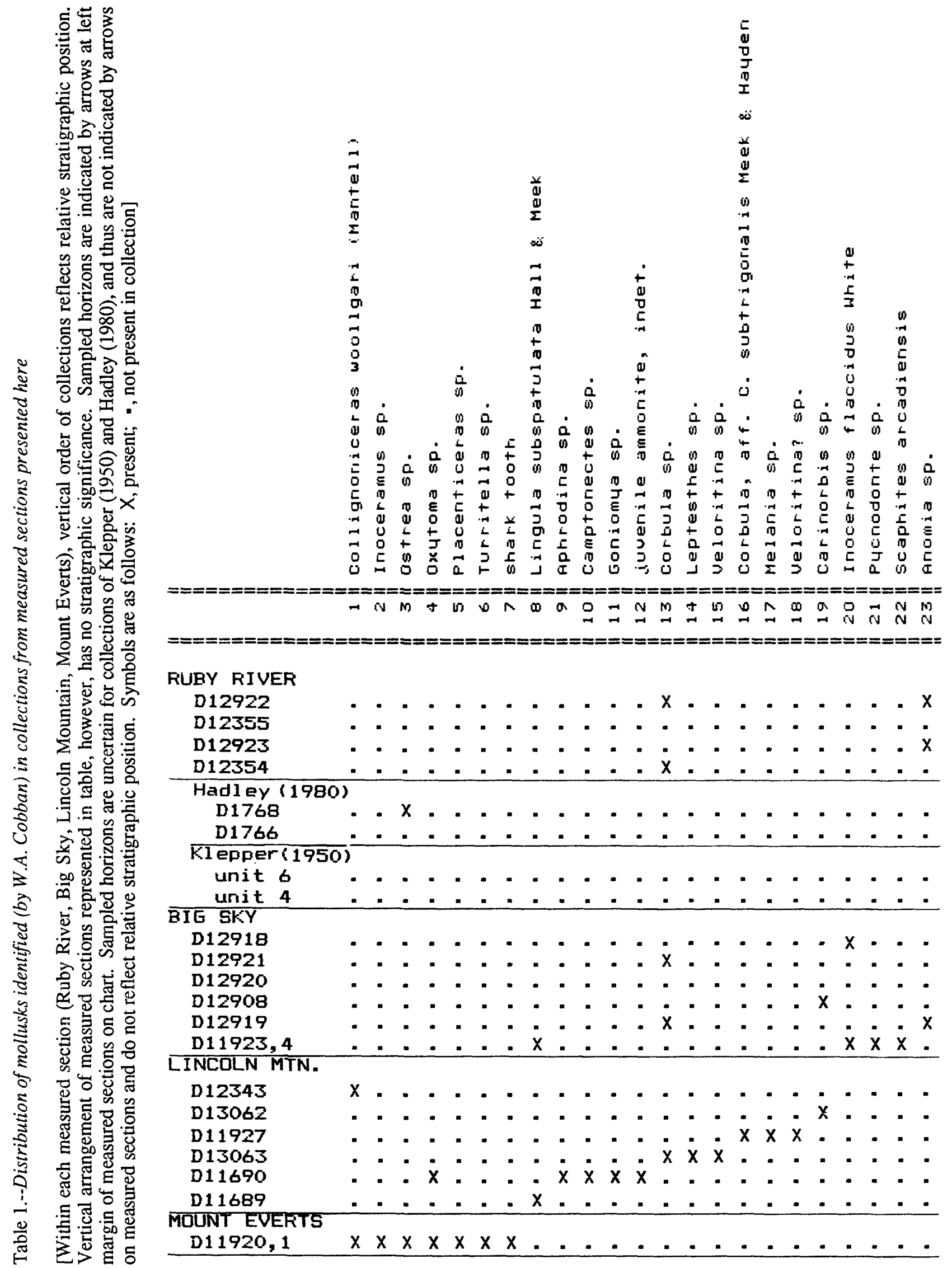




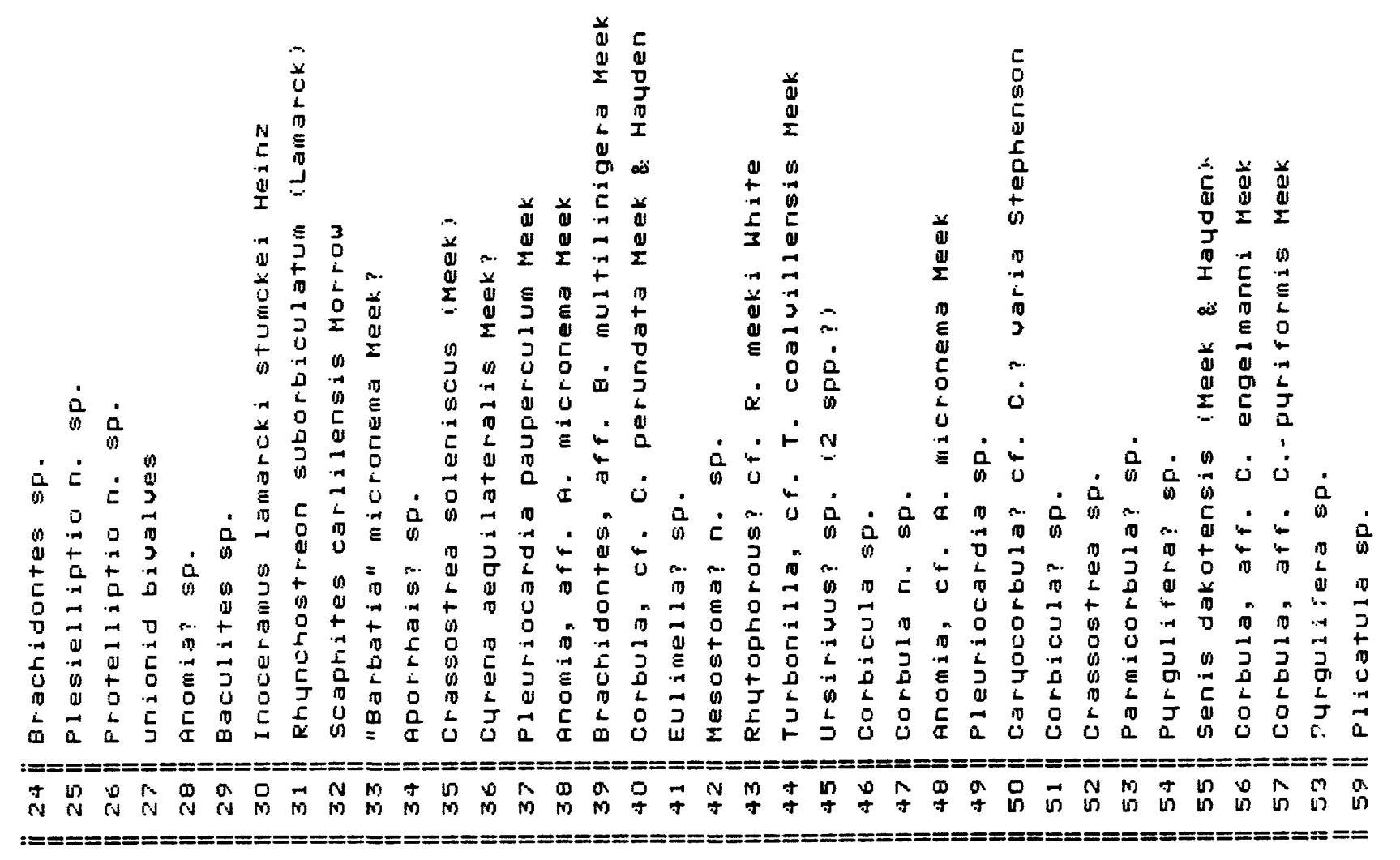

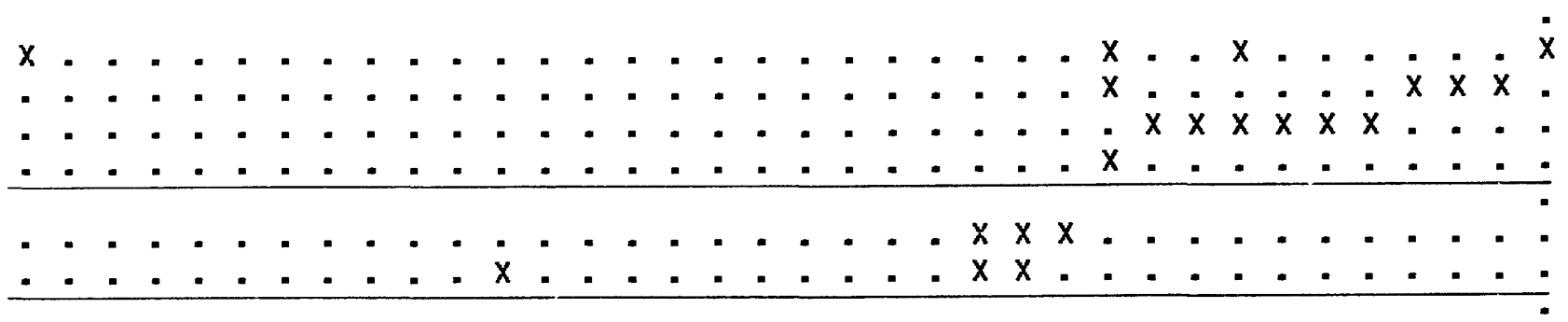

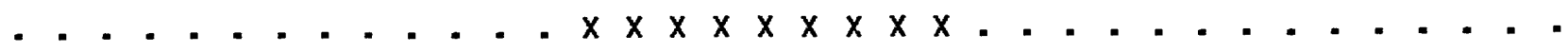

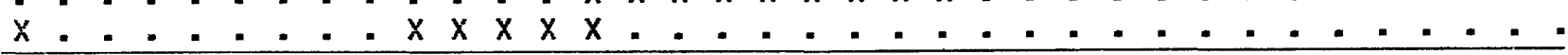

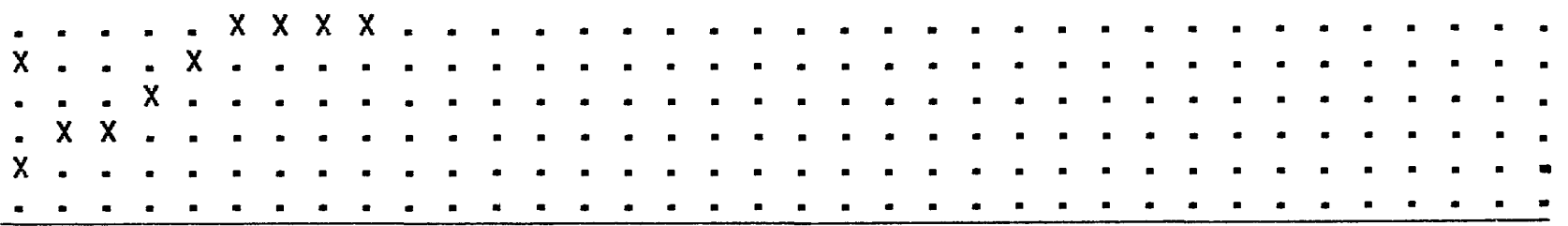

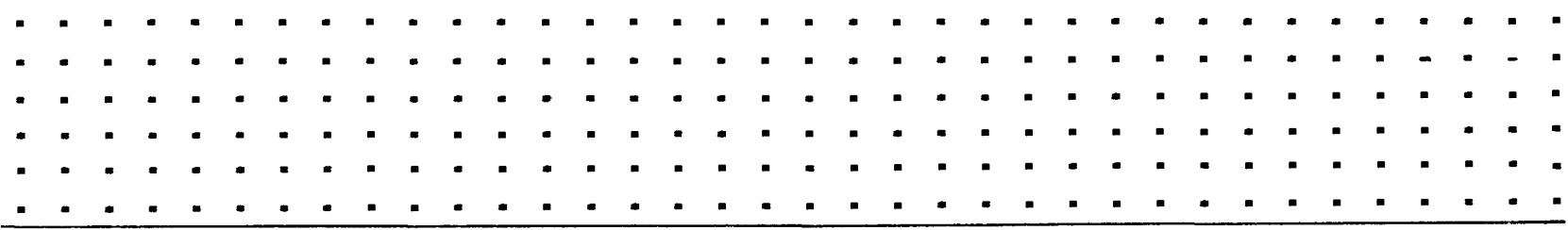


Table 2.--Alphabetized list of mollusk species. Index number corresponds to column number in table 1

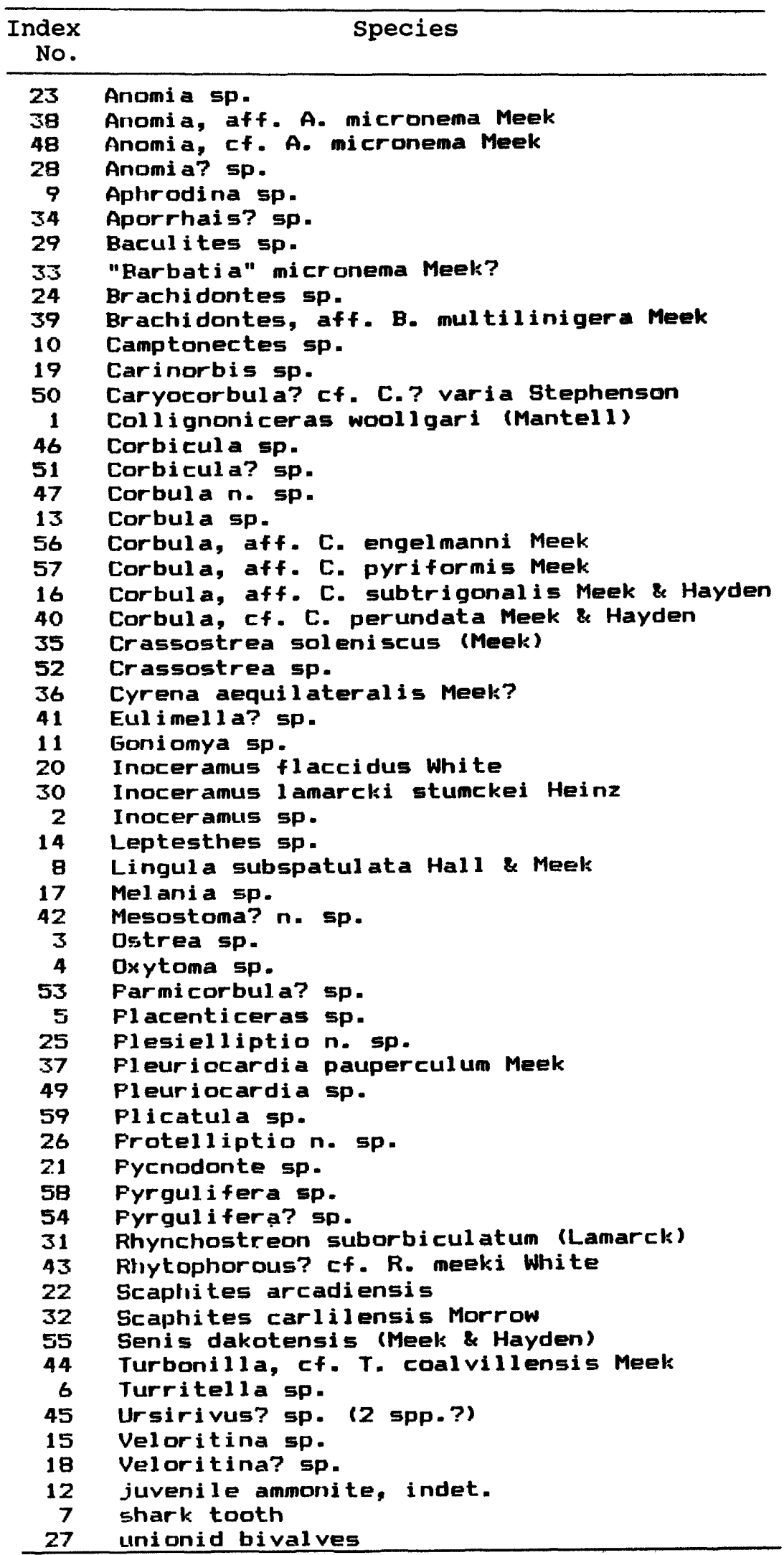



here

[Within each measured section (Ruby River, Lincoln Mountain, Mount Everts), vertical order of collections reflects relative stratigraphic position. Vertical arrangement of measured sections represented in table, however, has no stratigraphic significance. Sampled horizons are indicated by arrows at left margin of measured sections on crart. Species 1-12 are marine taxa; all others are nonmarine. Symbols are as follows: $X$, present; ", not present in collection] 
Table 4.--Alphabetized list of palynomorph species. Index number corresponds to column number in table 3

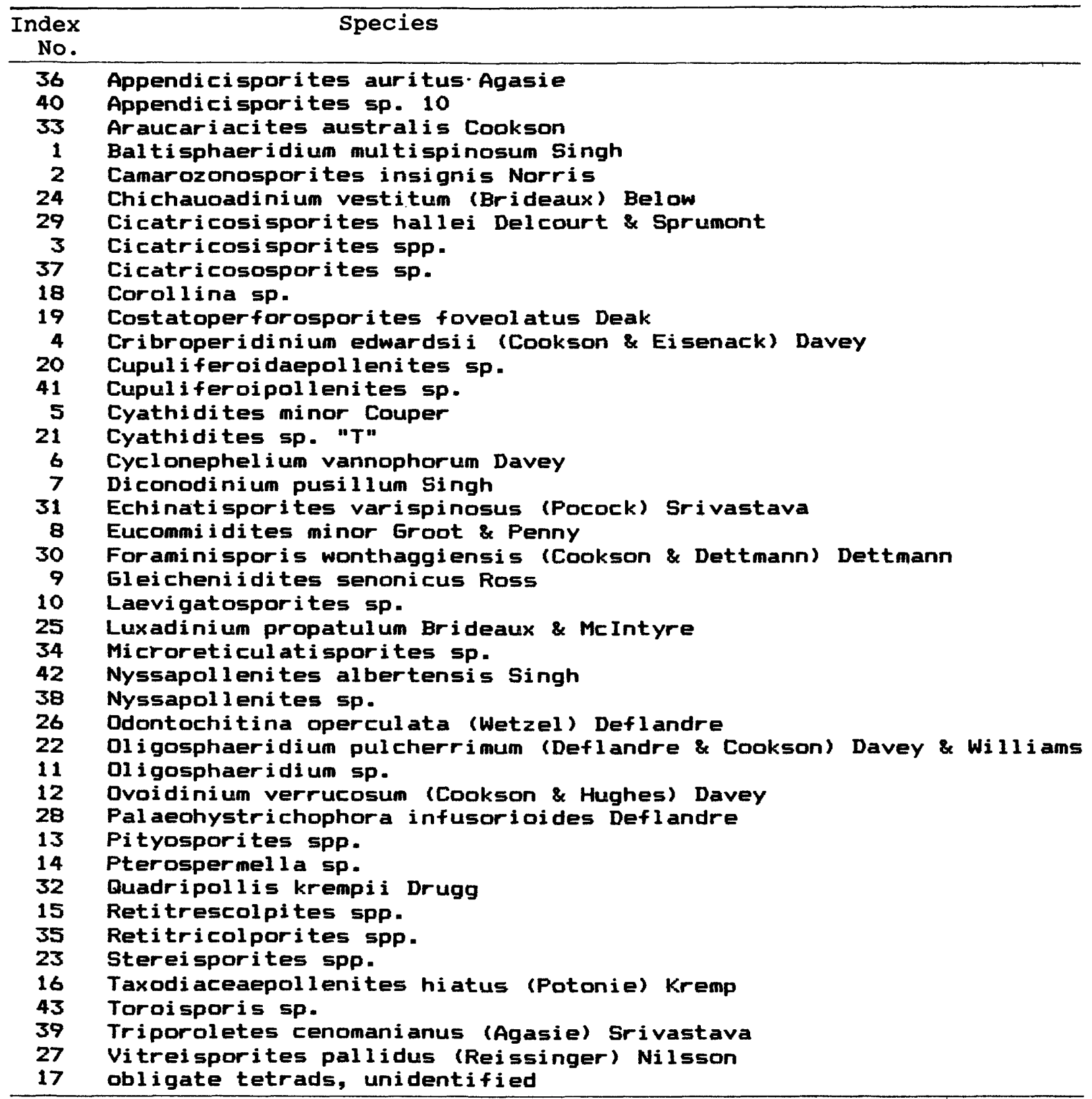

